\title{
Age-specific survival and reproductive rates of Mediterranean monk seals at the Cabo Blanco Peninsula, West Africa
}

\author{
Pablo Fernández de Larrinoa ${ }^{1, *}$, Jason D. Baker ${ }^{2}$, Miguel A. Cedenilla ${ }^{1}$, \\ Albert L. Harting ${ }^{3}$, Moulaye 0 . Haye ${ }^{1}$, Mercedes Muñoz ${ }^{4}$, Hamdy M'Bareck ${ }^{1}$, \\ Abba M'Bareck ${ }^{1}$, Fernando Aparicio ${ }^{1}$, Soledad Centenera ${ }^{1}$, Luis M. González ${ }^{5}$ \\ ${ }^{1}$ Monk Seal Conservation Program, Fundación CBD-Habitat, 28002 Madrid, Spain \\ ${ }^{2}$ National Oceanic and Atmospheric Administration, Pacific Islands Fisheries Science Center, Protected Species Division, \\ Honolulu, HI 96818, USA \\ ${ }^{3}$ Harting Biological Consulting, Bozeman, MT 59715, USA \\ ${ }^{4}$ Center for Mediterranean Cooperation, International Union for Conservation of Nature, 29590 Malaga, Spain \\ ${ }^{5}$ Subdirección General de Biodiversidad Terrestre y Marina, Ministerio para la Transición Ecológica y el Reto Demográfico, \\ 28003 Madrid, Spain
}

\begin{abstract}
We provide the first complete set of survival rate estimates for the Endangered Mediterranean monk seal Monachus monachus from birth into adulthood, as well as the first agespecific reproductive rates for the species. From 2002 to 2016, we obtained individual seal live encounter data through non-invasive monitoring techniques that were analyzed to estimate vital rates of Mediterranean monk seals of the Cabo Blanco (Western Sahara/Mauritania) population. From birth to age $2 \mathrm{mo}$, when pups molt, survival averaged 0.59, ranging from 0.41 to 0.74 among cohorts. From birth to $1 \mathrm{yr}$ and from 1 to $2 \mathrm{yr}$, median estimated survival rates were 0.46 and 0.75 , respectively. Beyond 2 yr, survival estimates differed by sex: 0.94 for males and 0.97 for females. From 2005 to 2016, we estimated a mean gross reproductive rate of 0.71 . The youngest parturient females were $3 \mathrm{yr}$ old. Fitted age-specific reproductive rates increased beginning at age $3 \mathrm{yr}$ and exceeded 0.80 from age 6 to $17 \mathrm{yr}$. Despite low survival during the first 2 mo of life, the aggregate vital rates of the population are favorable for growth; a Leslie matrix containing our survival and fecundity estimates yielded an intrinsic growth rate of 1.058. Increasing abundance and favorable vital rates are a testament to the efficacy of the many measures taken to promote the conservation of this population.
\end{abstract}

KEY WORDS: Mediterranean monk seal $\cdot$ Monachus monachus $\cdot$ Survival rates $\cdot$ Reproductive rates $\cdot$ Fecundity $\cdot$ Cabo Blanco

\section{INTRODUCTION}

Survival, fecundity, immigration, and emigration are the parameters that together determine population abundance over time. Estimating these vital rates and elucidating links between their covariation with intrinsic and extrinsic environmental parameters are fundamental to applied population ecology (Frederiksen et al. 2014). Evaluating vital rates also informs

${ }^{*}$ Corresponding author:

pablo.fernandezdelarrinoa@cbd-habitat.com applied conservation biology, including diagnosing declines and recovery planning (Caughley \& Gunn 1996, Dahlgren et al. 2016). Analysis of live encounter data from individually marked animals is a preferred approach for estimating demographic parameters in wildlife populations (Sandercock 2006).

The Endangered Mediterranean monk seal Monachus monachus is the rarest species of pinniped; the most recent published assessment reports that fewer

(C) The authors and outside the USA the US Government 2021 Open Access under Creative Commons by Attribution Licence. Use, distribution and reproduction are unrestricted. Authors and original publication must be credited. 
than 700 individuals remain (Karamanlidis et al. 2016). The seals almost exclusively come to shore to rest, give birth, and nurse their pups inside sea caves, a behavior which has perhaps facilitated the species' persistence. Although the range of the monk seal once encompassed the Black Sea, Mediterranean Sea, and the eastern Atlantic (including mainland Africa and the oceanic island groups of Macaronesia), currently only 3 isolated subpopulations are known to remain (González 2015, Karamanlidis et al. 2016). In the eastern Mediterranean, some 350-450 seals are widely dispersed among islands and mainland coasts, primarily in Greece and Turkey, but also in several other countries (Gucu et al. 2009, Karamanlidis \& Dendrinos 2015, Karamanlidis et al. 2019, Nicolaou et al. 2019, Fioravanti et al. 2020, Beton et al. 2021). In the eastern Atlantic, 2 highly localized subpopulations persist. Approximately 20 individuals reside in the Madeira Archipelago (R. Pires unpublished data), and the largest single aggregation of monk seals (more than 300 in total) occurs at Cabo Blanco, Western Sahara/Mauritania (Fig. 1). Fortunately, there are indications that all 3 subpopulations may be increasing in abundance to some degree (Karamanlidis \& Dendrinos 2015).

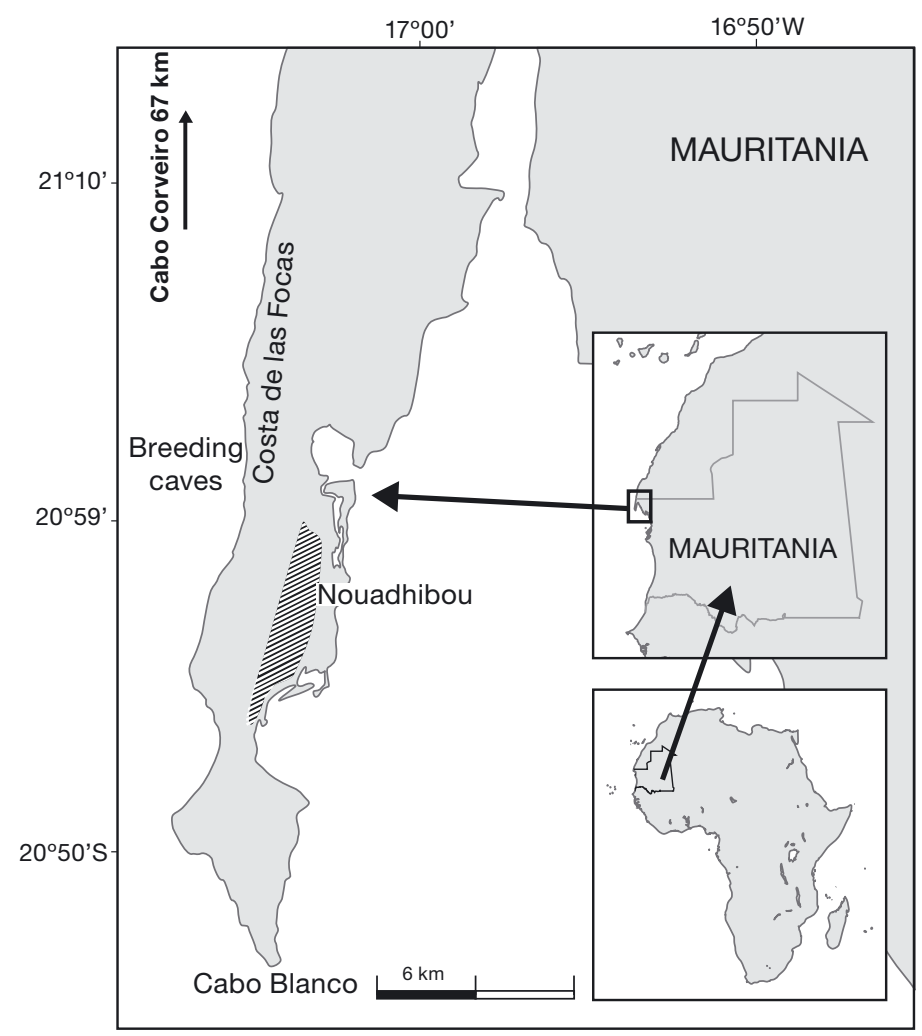

Fig. 1. Cabo Blanco peninsula, showing the area known as Costa de las Focas (Seal Coast), the location of the breeding caves, and the city of Nouadhibou
The Cabo Blanco seals almost exclusively come ashore on beaches inside 3 caves, all of which are located along approximately $1 \mathrm{~km}$ of shoreline. They forage in nearby waters, and a no-fishing marine area is designated from the coast out to 12 nautical miles and encompassing approximately 28 nautical miles of shoreline flanking the caves. Notwithstanding recent positive trends (Martínez-Jauregui et al. 2012), the concentration of the entire population in such a small range makes it vulnerable to a variety of threats. In 1997, a mass mortality event reduced the population by about two-thirds from 317 to 109 individuals (Forcada et al. 1999). The cause(s) of the dieoff remain(s) undetermined, although leading hypotheses include biotoxin poisoning and a morbillivirus outbreak (Osterhaus et al. 1997, Hernández et al. 1998, Reyero et al.1999). Another such event could recur at any time. On multiple occasions, all or portions of caves used by seals at Cabo Blanco have collapsed, demonstrating the potential for these critical habitats to be degraded or entirely destroyed (González et al. 1997). The caves are directly exposed to episodic heavy surf and high tides, which contribute to high mortality of young pups (Gazo et al. 2000). The monk seal caves are situated just $7 \mathrm{~km}$ from Nouadhibou, a rapidly growing commercial center with a population of over 100000 . Both local artisanal and large-scale modern foreign fishing fleets operate in the waters adjacent to Cabo Blanco peninsula (Belhabib et al. 2012). This proximity makes the Cabo Blanco monk seals vulnerable to increasing direct and indirect human impacts such as pollution, active fishery bycatch, and debris entanglement.

The shocking losses that occurred during the 1997 mass mortality prompted the development of a plan for the recovery of the monk seal in the eastern Atlantic coordinated by 4 countries: Mauritania, Morocco, Spain, and Portugal (González et al. 2006). The Action Plan called for conservation, research, and monitoring objectives. These included estimating demographic parameters, such as productivity and age-specific survival. Following the mass mortality, the Cabo Blanco monk seal population has rebounded impressively, no doubt in part due to the protections afforded under the Action Plan (Martínez-Jauregui et al. 2012).

Pinniped demographic studies typically rely on applied flipper tags or, less commonly, branding to mark individuals (Loughlin et al. 2010). A few research programs have used photographic identification based on persistent natural marks (usually because capturing a sufficient sample of study subjects to apply marks is infeasible) to estimate seal abundance or vital rates (Mackey et al. 2008, Koivuniemi et 
al. 2019). The perilous status of the Cabo Blanco monk seal population following the 1997 mass mortality, coupled with known negative impacts of human disturbance on the species throughout its range, prompted the 2006 Action Plan to emphasize handsoff methods. Specifically, 'For population monitoring and studies of monk seal biology, non-invasive techniques shall be used, avoiding actions that would involve disturbance to seals at breeding and resting sites' (González et al. 2006, p. 235). Photographic identification techniques had already been developed for studying monk seals at Cabo Blanco prior to the mass mortality event (Forcada \& Aguilar 2000), and were further refined and used almost exclusively for obtaining individual resighting histories thereafter.

Most published estimates of Mediterranean monk seal survival and reproductive rates have been based on research at Cabo Blanco, which has long been the only colony with a sizeable population concentrated in a small area with the potential for observation and collection of live encounter data. Key findings of the studies published to date (Table 1) were that early pup survival is relatively low compared to other pinnipeds, whereas seals older than 2.5 yr showed high survival (at least subsequent to the 1997 mass mortality event). Survival from age 2 mo until approximately 2.5 yr has not been estimated, representing an important gap in information about the life history of this species. Reported birth rates prior to the mortality event were found to be unusually low compared to other pinnipeds (Gazo et al. 1999), but improved after the event (González et al. 2002). The latter investigators, however, discussed uncertainty and bias in both the total pups born and the number

Table 1. Previously published estimates of sex- and age-class-specific survival and gross reproductive rates (pups born divided by the number of assumed reproductive-age females) of Mediterranean monk seals at Cabo Blanco

\begin{tabular}{|c|c|c|c|c|}
\hline Age class & Sex & Data years & Survival (95\% CI) & Source \\
\hline $0-2 \mathrm{mo}$ & Both & 1993-1997 & 0.47 & Gazo et al. (2000) \\
\hline $0-2 \mathrm{mo}$ & Both & 1995-1997 & $0.52(0.42-0.61)$ & González et al. (2002) \\
\hline $0-2 \mathrm{mo}$ & Both & $1997-1998,2000$ & $0.57(0.46-0.70)$ & González et al. (2002) \\
\hline $2.5-4 \mathrm{yr}$ & Both & 2003-2007 & $0.81(0.68-0.90)$ & $\begin{array}{l}\text { Martínez-Jauregui et } \\
\text { al. (2012) }\end{array}$ \\
\hline$>4 \mathrm{yr}$ & Female & $2003-2007$ & $0.99(0.93-1.00)$ & $\begin{array}{l}\text { Martínez-Jauregui et } \\
\text { al. (2012) }\end{array}$ \\
\hline$>4 \mathrm{yr}$ & Male & $2003-2007$ & $0.87(0.81-0.94)$ & $\begin{array}{l}\text { Martínez-Jauregui et } \\
\text { al. (2012) }\end{array}$ \\
\hline Age class & Sex & Data years & Birth rate range & Source \\
\hline$>2 \mathrm{yr}$ & Female & $2003-2007$ & $0.30-0.43$ & Gazo et al. (1999) \\
\hline$>2 \mathrm{yr}$ & Female & 1998 & 0.63 & González et al. (2002) \\
\hline
\end{tabular}

of reproductive-age females used to estimate birth rates. In this study, we analyzed more than a decade of live encounter data to estimate vital rates of Mediterranean monk seals at Cabo Blanco, encompassing a period of population increase and enhanced conservation measures under the Action Plan. We provide the first complete set of survival rate estimates for Mediterranean monk seals from birth into adulthood, and the first estimates of age-specific reproductive rates for the species.

\section{METHODS}

\subsection{Study area and surveillance methods}

The coastline from Cabo Corveiro $\left(21^{\circ} 48^{\prime} \mathrm{N}\right.$, $\left.16^{\circ} 58^{\prime} \mathrm{W}\right)$ to Cabo Blanco $\left(20^{\circ} 46^{\prime} \mathrm{N}, 17^{\circ} 03^{\prime} \mathrm{W}\right)$, Western Sahara/Mauritania, comprises cliff and sandy beach sections. Seals move along this entire coast but almost exclusively come ashore inside 3 caves at the south end of the cliff area known as Costa de las Focas $\left(21^{\circ} 02^{\prime} \mathrm{N}, 17^{\circ} 03^{\prime} \mathrm{W}\right)$, on the west coast of the Cabo Blanco peninsula (Fig. 1). Seals aggregate in these caves, using mainly two of them for giving birth and nursing pups.

Since 2003, the population has been continuously surveyed using non-invasive methods. All seals were individually recognizable based upon natural marks, including scars and fur patterns. Individual identification and reproductive data were obtained in 2 ways. First, permanent remote-controlled video cameras installed at the entrance of the caves provided video recordings of the inner beaches of the 2 breeding caves almost daily. Analysis of the video allows for documentation of births, maternal behavior, and identification of individual seals. The video monitoring system has been in place since June 2000. Additionally, seals in the water were identified from still photographs obtained from clifftops above the cave entrances, using methods similar to those described by Forcada \& Aguilar (2000). From 2003 to 2016 (with the exception of 2004), a dedicated photo-identification annual survey with a mean of $25 \mathrm{~d}$ (range 20-30 d; approximately $4 \mathrm{~h}$ of effort each day) was conducted, mostly in September and October. This was augmented 
between 2010 and 2016 with a mean of 50 single-day (range 20-93 d) opportunistic photo-identification sessions distributed throughout the year. These opportunistic sessions lasted from a few minutes up to several hours, depending upon the presence of seals and sighting conditions. A total of 134931 still photographs suitable for identification were obtained during 2003-2016.

Multiple lines of evidence support the conclusion that the Cabo Blanco population is closed to immigration and emigration. Photo-identification has been conducted in the nearest Mediterranean monk seal population, located in the Madeira archipelago, more than $1000 \mathrm{~km}$ north of Cabo Blanco (R. Pires unpubl. data). Photos from both populations have been jointly analyzed, and no individuals have been detected in both populations. Additionally, 35 and 3 individuals have been tracked with telemetry devices from Cabo Blanco and Madeira, respectively, none of which was observed to leave its home population (P. Fernández de Larrinoa unpubl. data). Finally, all visual observations of monk seals reported on the Atlantic coast of Africa in the last $20 \mathrm{yr}$ have occurred within approximately $80 \mathrm{~km}$ of the caves at Costa de las Focas.

\subsection{Individual identification}

Live encounter data were shaped by reliance on photographic identification to follow individuals over time and the ontogenetic characteristics of Mediterranean monk seal pelage patterns and scarring. Pups are born with mostly black lanugo except for a highly distinctive yellowish-white ventral patch. The shape of the ventral patch is sexually dimorphic, and both its outline and a pattern of black spotting within the patch are unique to individuals (Badosa et al. 1998). Thus, observing the ventral patch is a means for both sex determination and individual identification of neonates.

At approximately 2 (and no more than 3) mo of age, pups complete their first molt to a fairly uniform gray color, and their unique pelage features disappear (Samaranch \& González 2000, Badosa et al. 2006). During a subsequent phase, most of the seals at Cabo Blanco are indistinguishable. Over time, seals accrue sufficient marks (scars) as to be individually identifiable, and are entered into a photographic identification catalog of subadults. Seals typically enter this subadult catalog at 2 or $3 \mathrm{yr}$ of age (see Section 3), and from that point forward their identities are maintained through photographic resightings.
The ages of a subset of Mediterranean monk seals at Cabo Blanco are known, because some pups acquired permanent scars or had distinctive pelage lateral lines that remained even after they molted. These seals had identities maintained from birth through adulthood. Moreover, male Mediterranean monk seals molt to mostly black pelage as adults, but with a ventral patch matching that of their lanugo (Samaranch \& González 2000, Badosa et al. 2006, Cedenilla et al. 2017). Consequently, some adult males can be linked to their pup identities (and thereby birth year) based upon their pup and adult ventral patterns. Scars on these males can also be used to link to their subadult and adult identities.

\subsection{Survival estimation}

We used different approaches to estimate Mediterranean monk seal survival rates during 3 distinct periods of life: birth to age 2 mo $\left(\phi_{0-2 \mathrm{mo}}\right), 2$ mo to $2 \mathrm{yr}$ $\left(\phi_{2 \mathrm{mo}-2 \mathrm{yr}}\right)$, and $2 \mathrm{yr}$ and older $\left(\phi_{2 \mathrm{yr}}, \phi_{3 \mathrm{yr}}, \ldots\right)$. Because daily video surveillance in the caves was conducted year-round beginning in 2001, nearly all births are believed to have been detected since 2001. Further, pups are closely monitored with the video system until their first molt. Some pups are observed dead either in the caves or on nearby beaches, and others simply go missing and are treated as having died because they cannot survive without their mothers at such a young age. Thus, survival rates were simply calculated as the proportion of those born that remained alive at 2 mo of age during 2002 to 2016 . Binomial confidence intervals for these estimates were calculated with Wilson's method using the R package 'Hmisc' (Wilson 1927, Agresti \& Coull 1998, Harrell 2015) in RStudio Version 1.3.1093.

Estimating survival from 2 mo to 2 yr was somewhat more complicated. Because the Cabo Blanco population is closed, all of the seals that enter the subadult catalog represent survivors born a few years prior. If the ages of all subadults were known, one could simply calculate the number of survivors to at least age 2 yr divided by the known number of pups at age 2 mo from the same cohort. However, because the ages of most seals were not known, we incorporated age uncertainty into survival rate estimates. To do this, we used the distribution of ages when known-age seals had entered the subadult catalog. Separate distributions were determined for male and female known-age seals. A Monte Carlo process was then used to generate 10000 realizations of the sex-specific number of survivors to at least age 
2 yr from specific cohorts. In each trial, the known number of survivors accounted for by the known-age seals remained fixed, and ages were randomly assigned to the remaining seals. For unknown-age subadults whose sex was known, an age was randomly drawn from the multinomial age distributions representing the ages at which known-aged seals of the corresponding gender entered the subadult catalog. The sex of some subadults was unknown, typically because they were documented as identifiable but their sex was not confirmed before they ceased being resighted. For these individuals, a sex was first assigned by randomly drawing from a binomial with $\mathrm{p}=0.50$, then a random age was assigned as above.

For each randomized trial, sex- and age-specific survival rates were calculated by dividing the randomized number of survivors to at least age $2 \mathrm{yr}$ by the number known to have been alive at age 2 mo. Some trials yielded survival rates greater than 1.0, because the random age allocation resulted in an impossible outcome whereby the number of surviving males or females from a given cohort exceeded the corresponding number known to have been alive at age 2 mo. Any trial yielding a survival rate exceeding 1 was discarded, and Monte Carlo sampling was repeated until 10000 realizations in which all calculated survival rates were $\leq 1$ had been obtained. The number of pups alive at age 2 mo was available for the 2002-2016 cohorts, whereas information on subadults was available for 2005-2015. To reduce bias, survival from age 2 mo to $2 \mathrm{yr}$ was estimated only for the cohorts (2003-2012) that had resighting opportunities at both ages 2 and $3 \mathrm{yr}$.

We estimated survival from age 2 yr and older using Cormack-Jolly-Seber (CJS) capture-recapture models in the R package 'marked' (Laake et al. 2013). We treated entry into the subadult catalog as the initial 'capture' event, resightings in subsequent years as 'recaptures,' and included capture histories from 2005 to 2015. In the package 'marked,' age at first capture can be specified for each individual. Because the age when most seals entered the subadult catalog was not known precisely and the sex of some was also unknown, we again employed the method described above to randomly assign ages and sexes at first capture to seals for which these factors were unknown. We began by determining whether the best fitting model structure (according to Akaike's information criterion, AIC) varied with different random age and sex assignments. For computational efficiency, we initially generated just 5 sample sets of capture histories and ranked 10 different candidate CJS models fitted to each. Modeling proceeded by first fitting recapture probability ( $p$, a nuisance parameter), and then testing various formulations of survival parameters $(\phi)$. Initially, a model with a different $p$ parameter for each year was fitted, and subsequently grouped-year models were explored. Models with separate recapture probabilities for males and females were also tested. Once a preferred recapture probability structure was determined, various formulations for survival were modeled including the factors age, sex, and year. In addition to evaluating age-specific survival models, models with 4 age parameters (for ages 1, 2, 3, and $4+y r)$ were fitted. While this analysis was focused on estimating survival beyond age $2 \mathrm{yr}$, a parameter for age 1 yr survival was necessarily included because a small proportion of seals was randomly assigned an initial age of 1 yr.

Once a best fitting model structure was chosen, 1000 sets of capture histories with randomized initial age and sex assignments were generated and the same CJS model structure was fitted to each one. Finally, distributions of survival estimates that incorporate both uncertainty regarding seals' ages (and sexes) and parameter uncertainty were obtained. For each of the 1000 fitted CJS models, 1000 sets of logit scale survival coefficients were drawn from the multi-variate normal distribution specified using each model's parameters and associated variancecovariance matrix. The inverse-logit of the resulting values yielded survival rate distributions on the real scale.

\subsection{Reproductive rate estimation}

Age-specific reproductive rates were estimated from observations of female seals and counts of pups born from 2005 to 2016. Near-daily video surveillance coupled with photo-identification effort was sufficient to nearly completely tally the pups born and identify all, or nearly all, females of reproductive age alive in each of these years. Dead pups found on beaches near the caves were included in the pup counts, but it is possible that some pups were not counted if they died before they could be identified and did not wash up on beaches where they could be detected. The females were scored each year as to whether they were observed nursing a pup or exhibiting characteristic maternal behavior such as stealing or trying to steal a pup from another female, or distinctively searching for a pup. Pups associated with identified mothers are referred to as 'knownmaternity' pups. These are a subset of the total pups 
produced because in all years, more pups were identified than could be assigned to a female. These unknown-maternity cases could arise when motherpup pairs used a part of a breeding cave that was unobservable by the camera systems, when young pups died before their mothers could be identified, or when low-quality video images did not allow identification of the mother.

Age-specific reproductive rates were estimated using data from all years pooled. We devised a 2stage Monte Carlo simulation process to account for both uncertainty in the ages of many females as well as the unknown provenance of pups not assigned to a specific nursing mother. Some Cabo Blanco seals had known ages, whereas others were uncertain because they were first identified as subadults. Additionally, some seals that were first identified as adults had minimum ages. Whereas observation records were limited to 2005-2016 for calculating reproductive rates, we used all available data collected prior to 2015 to inform female age assignments.

At the initiation of each Monte Carlo iteration, unknown age females had an age randomly assigned at the year when they were first identified. For those first identified as subadults, an age was drawn just as described above for survival analyses. For minimumaged seals, a random age was selected from a multinomial vector containing the ages at which knownaged females were first observed to have given birth. This approach was chosen because parturition was the primary criterion for initially designating a female as an adult. Once an individual's random age was selected, her sequence of annual reproductive status observations was adjusted according to her assigned age. In this fashion, an individual female might, for example, be counted as having given birth at ages 5, 6, and $8 \mathrm{yr}$ in one simulation, and at ages 7 , 8 , and $10 \mathrm{yr}$ in another.

The first set of 1000 simulations with randomized age assignments produced distributions of age-specific reproductive rates using only the known-maternity pups. Each iteration yielded a set of age-specific rates calculated as the number of pups produced by females at each age divided by the total number of females known to be alive at each age in any year during 2005-2016. The denominators were calculated by counting each female as alive and present in the Cabo Blanco population from the first to the final year she was observed. Because the Cabo Blanco population is closed to emigration, in the few cases when females were missed and then resighted in at least one subsequent year, they were treated as present but unobserved. Likewise, female seals were counted as alive and present in years preceding their first observation year back to 2005 or their assigned birth year, whichever came later. A 5-parameter reproductive function (Harting 2002, Harting et al. 2007) was then fitted to the resulting distribution of age-specific rates:

$$
b_{x}=\frac{a \mathrm{e}^{f\left(1-\mathrm{e}^{g x}\right)}}{1+\mathrm{e}^{(c-d x)}}
$$

in which $b_{X}$ is the birth rate, $x$ is age in years, $a$ is the asymptote, $c$ and $d$ jointly govern the position and slope of the ascending segment of the curve, $f$ determines the longevity of the asymptotic rate, and $g$ governs the position and slope of senescent decline.

The preceding process merely yielded minimum age-specific reproductive rates, because it did not account for the unknown-maternity pups born during 2005-2016. The next set of simulations allocated unknown-maternity pups to individual ages in a manner consistent with the demography of the Cabo Blanco population. The allocation was based on the net maternity function (NMF) of the Cabo Blanco population, which we calculated as the product of the age-specific survivorship $\left(l_{x}\right)$ and the minimum agespecific reproductive rate divided by 2 (because the NMF pertains to female offspring only):

$$
\mathrm{NMF}_{x}=\frac{l_{x} \cdot b_{x}}{2}
$$

The NMF is the probability that a given female will both survive to a specific age and produce a female pup at that age, both of which must be considered when assessing the probability that an unknownmaternity pup was produced by a female of a particular age. Although the rates we used for $b_{x}$ are minima, we assumed that failing to match a pup with its mother was unrelated to the mother's age, so that the NMF represents the relative probabilities amongst ages.

A second set of simulations was conducted, in which every pup born was allocated to a maternal age class. The known-maternity pups and the number of females occurring at each age were tallied in exactly the same fashion as in the first set of simulations. For each unknown-maternity pup, a random maternal age was selected consistent with the relative probabilities from the NMF, and the numerator for that maternal age class was incremented accordingly. Each iteration produced a set of age-specific rates and the reproductive function was subsequently fitted to the resulting distributions of rates.

While conducting the age-specific reproductive rate simulations, we also calculated the gross repro- 
ductive rate (GRR) as the ratio of total pups to total reproductive-female years, pooling data over all years (2005-2016). For this calculation, all females older than age 2 yr were considered to be of reproductive age, consistent both with the youngest observed parous females in the Cabo Blanco population being age $3 \mathrm{yr}$, and with the criterion used in previous studies (Gazo et al. 1999, González et al. 2002).

\subsection{Intrinsic rate of population growth}

We constructed a simple Leslie matrix containing the point estimates of survival and fecundity reported herein (with maximum age of $24 \mathrm{yr}$ ). The intrinsic growth rate was then determined using the R package 'demogR' (Jones 2007).

\section{RESULTS}

\subsection{Survival from birth to age 2 mo}

During 2002-2016, 24 to 82 pups were born each year. While the point estimates of survival to 2 mo of age varied considerably among years (ranging from 0.41 to 0.74 ), the $95 \%$ confidence intervals (CI) overlapped, indicating no statistically significant temporal patterns (Fig. 2). Further, there was no difference in survival of male and female pups for all years combined (Table 2). The combined estimated rate for all pups in all years $(0.59, \mathrm{~N}=763)$ was slightly lower than for either known males or females, as this calculation included 25 pups whose gender was not determined, of which 24 died prior to 2 mo of age. lapping distributions, except in 2004 (Fig. 3). Median cohort survival rates for both sexes combined varied from 0.46 to 0.81 . The median survival rate across all years was 0.59 (0.58-0.60). Male and female survival rate distributions for all years combined were very similar (Table 2).

Our estimates of survival from 2 mo to 2 yr of age are somewhat negatively biased, in that some seals first became identifiable and were included in adult male and breeding female catalogs without ever having been identifiable as subadults. The number of such cases was small for any given cohort (Table 4), but they do represent some survivors for which we did not account. The earliest year included in Table 4 is 2006, because adults are at least $3 \mathrm{yr}$ old and our earliest cohort for survival estimation is 2003. Because the most recent such cases occurred in 2012,

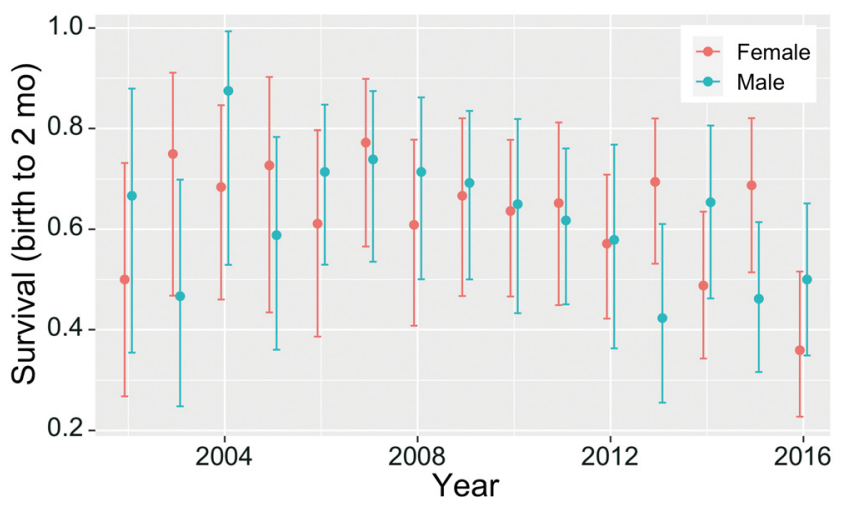

Fig. 2. Survival of female and male Mediterranean monk seal pups at Cabo Blanco from birth until 2 mo of age during 2002-2016. Pups $(n=25)$ whose genders were not determined are not included in the survival rates for knownsex pups shown here. Binomial 95\% confidence intervals are indicated by vertical lines

\subsection{Survival from 2 mo to $2 \mathrm{yr}$}

A total of 287 pups survived to age 2 mo from 2003 to 2012 . A total of 183 seals entered the subadult catalog during 2005-2015, including 53 of known age and 130 whose ages were not known. The multinomial distributions of ages at which known-age female and male seals entered the subadult catalog were the bases for randomly assigning ages to the seals whose birth years were not known (Table 3 ).

Survival from 2 mo to $2 \mathrm{yr}\left(\phi_{2 \mathrm{mo}-2 \mathrm{yr}}\right)$ varied considerably among cohorts, and annual sex-specific rates had over-
Table 2. Estimated survival rates of Mediterranean monk seals at Cabo Blanco by age class and sex. Birth to 2 mo binomial means are shown, with $95 \%$ confidence intervals in parentheses. All other rates are medians of distributions with center $95 \%$ percentile limits in parentheses. Because there were no sex differences in survival rates from birth to $2 \mathrm{mo}$, nor from 2 mo to $2 \mathrm{yr}$, the annualized rates for the first and second years $\left(\phi_{0}, \phi_{1}\right)$ were calculated only for both sexes combined. Conversely, because survival did differ among the sexes after $2 \mathrm{yr}$, no combined sex rate was derived for this age class. Dashes indicate parameters for which either sex-specific or combined sex estimates were not obtained

\begin{tabular}{|lccc|}
\hline Age class & Females & Males & All \\
\hline Birth to 2 mo $\left(\phi_{0-2 \mathrm{mo}}\right)$ & $0.61(0.56-0.65)$ & $0.60(0.55-0.65)$ & $0.59(0.55-0.62)$ \\
2 mo to $2 \mathrm{yr}\left(\phi_{2 \mathrm{mo}-2 \mathrm{yr}}\right)$ & $0.58(0.55-0.62)$ & $0.60(0.57-0.63)$ & $0.59(0.58-0.60)$ \\
Birth to $1 \mathrm{yr}\left(\phi_{0}\right)$ & - & - & $0.46(0.43-0.49)$ \\
1 to 2 yr $\left(\phi_{1}\right)$ & - & - & $0.75(0.74-0.76)$ \\
$2+\mathrm{yr}\left(\phi_{2 \mathrm{yr}+}\right)$ & $0.97(0.95-0.99)$ & $0.94(0.90-0.96)$ & - \\
\hline
\end{tabular}




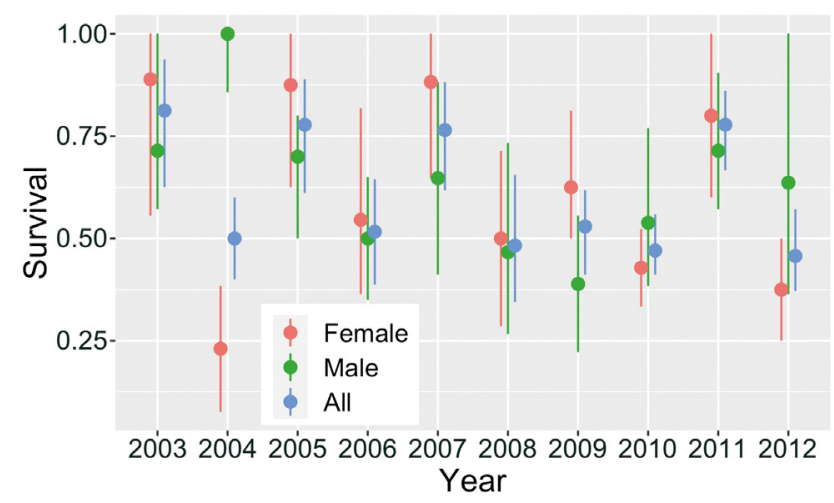

Fig. 3. Survival of Mediterranean monk seals at Cabo Blanco from age 2 mo to 2 yr during 2003-2012. Empirical center

$95^{\text {th }}$ percentile intervals are indicated by vertical lines

Table 3. Ages at which 53 male and female Mediterranean monk seals at Cabo Blanco were individually identifiable and entered the subadult photographic identification catalog. Also shown are the ages when 17 known-age female seals were first observed to be parturient

\begin{tabular}{|lccc|}
\hline Age $(\mathrm{yr})$ & Males & Females & First parturition \\
\hline 1 & 1 & 0 & 0 \\
2 & 6 & 2 & 0 \\
3 & 23 & 20 & 3 \\
4 & 0 & 1 & 6 \\
5 & 0 & 0 & 5 \\
6 & 0 & 0 & 3 \\
\hline
\end{tabular}

Table 4. Number of Mediterranean monk seals that entered the breeding female and adult male photographic identification catalogs, without having been documented as subadults, by calendar year. These individuals were likely born during 2003-2009 and represent a source of negative bias in survival estimates from age 2 mo to 2 yr for those cohorts

\begin{tabular}{|ccc|}
\hline Year & Breeding females & Adult males \\
\hline 2006 & 3 & 2 \\
2007 & 1 & 1 \\
2008 & 0 & 0 \\
2009 & 1 & 2 \\
2010 & 1 & 3 \\
2011 & 1 & 1 \\
2012 & 0 & 2 \\
2013 & 0 & 0 \\
2014 & 0 & 0 \\
2015 & 0 & 0 \\
\hline
\end{tabular}

the negative bias would have affected only the 20032009 cohorts. We acknowledge that this negative bias, albeit small, does exist.

Survival rates for this life stage nominally apply to a 22 mo period from age 2 mo to $2 \mathrm{yr}$. This interval is approximate because seals were scored as alive at age $2 \mathrm{yr}$ if they were seen at any time during or after the calendar year 2 yr subsequent to their known or randomly assigned birth year. Some individuals may have been resighted when they were slightly younger than their second birthday, whereas most survivors were not resighted until the third year after birth (Table 3). To the extent that some seals survived to age 2 yr, were not identified as subadults, and then died before their third year, these survival rates are negatively biased.

We obtained annualized survival rates for the first $\left(\phi_{0}\right)$ and second years of life $\left(\phi_{1}\right)$ by assuming that survival was constant during the 22 mo long interval $\left(\phi_{2 \mathrm{mo}-2 \mathrm{yr}}\right)$ and making the following calculations:

$$
\phi_{0}=\phi_{0-2 \mathrm{mo}} \cdot\left(\phi_{2 \mathrm{mo}-2 \mathrm{yr}}\right)^{10 / 22}
$$

and

$$
\phi_{1}=\left(\phi_{2 \mathrm{mo}-2 \mathrm{yr}}\right)^{12 / 22}
$$

To account for uncertainty, for $\phi_{0}$ we drew 10000 random values from the binomial distribution estimated for $\phi_{0-2 \mathrm{mo}}(\mathrm{p}=0.59, \mathrm{n}=763)$ and multiplied them by the previously generated 10000 estimates of $\phi_{2 \mathrm{mo}-2 \mathrm{yr}}$ raised to the $10 / 22$ power. For $\phi_{1}$, we simply raised each of the 10000 estimates of $\phi_{2 \text { mo-2yr }}$ to the $12 / 22$ power. Given there were no sex differences in $\phi_{0-2 \mathrm{mo}}$ or $\phi_{2 \mathrm{mo}-2 \mathrm{yr}}$, we only calculated $\phi_{0}$ and $\phi_{1}$ for both sexes combined (Table 2). Median first-year survival, $\phi_{0}$, was 0.46 and median second-year survival, $\phi_{1}$, was 0.75 (Table 2, Fig. 4).

\subsection{Survival beyond age 2 yr}

Survival after age 2 yr was estimated using capture histories of 168 seals (47 known and 121 unknown age) that entered the subadult catalog from 2005 to 2014 and were resighted through 2015. Among them

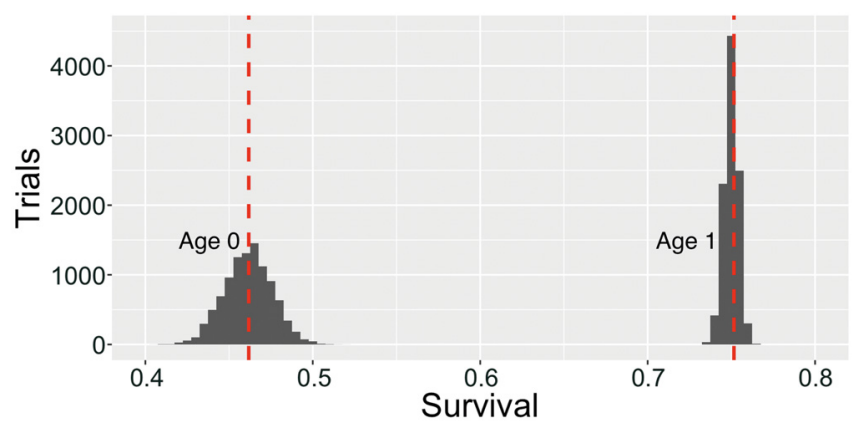

Fig. 4. Estimated distributions of first $\left(\phi_{0}\right)$ and second $\left(\phi_{1}\right)$ year survival of Mediterranean monk seals at Cabo Blanco. Vertical dashed red lines indicate median values of each distribution. 'Trials' refers to the number of iterations used in the Monte Carlo simulation, as described in detail in Section 2.3 
Table 5. Akaike's information criterion (AIC) values of 10 Cormack-Jolly-Seber (CJS) models fitted to each of 5 trial sets of Mediterranean monk seal capture histories with randomized assignments of age and sex. Models are ranked, with 1 indicating the best-fitting model based on the lowest AIC value (shown in bold). Model specification for survival ( $\phi$ ) and recapture probability $(p)$ parameters are shown. Most specifications are self-explanatory (constant, sex, age) and others are abbreviated as follows: 'Time' fits a parameter for each year, 'grouped years' fits 2 parameters (one for 2006 and 2015, one for 2007-2014), 'grouped ages' fits 4 parameters for the following ages $(1,2,3$, and $\geq 4 \mathrm{yr})$. These models were used to estimate survival of seals age 2 yr and older. However, an age 1 yr survival parameter was necessarily included because a few seals were randomly assigned an initial age of $1 \mathrm{yr}$. 'Par' indicates the number of parameters fitted in each model

\begin{tabular}{|c|c|c|c|c|c|c|c|c|c|c|c|c|}
\hline \multicolumn{2}{|c|}{$\longrightarrow$ Model specification -} & \multirow[t]{2}{*}{ Par } & \multicolumn{5}{|c|}{-Model AIC by trial- } & \multicolumn{5}{|c|}{ —Model rank by trial- } \\
\hline$\phi$ & $p$ & & 1 & 2 & 3 & 4 & 5 & 1 & 2 & 3 & 4 & 5 \\
\hline Constant & Constant & 2 & 518.85 & 518.85 & 518.85 & 518.85 & 518.85 & 10 & 10 & 10 & 10 & 10 \\
\hline Constant & Time & 11 & 515.26 & 515.26 & 515.26 & 515.26 & 515.26 & 9 & 9 & 9 & 9 & 9 \\
\hline Constant & Grouped years & 3 & 503.76 & 503.76 & 503.76 & 503.76 & 503.76 & 5 & 4 & 5 & 6 & 7 \\
\hline Constant & Sex + grouped years & 4 & 496.87 & 498.92 & 495.61 & 499.16 & 498.58 & 3 & 2 & 2 & 3 & 2 \\
\hline Sex & Sex + grouped years & 5 & 492.48 & 498.42 & 491.65 & 494.68 & 496.02 & 1 & 1 & 1 & 1 & 1 \\
\hline Time & Sex + grouped years & 13 & 505.68 & 507.53 & 504.90 & 508.24 & 507.75 & 7 & 7 & 7 & 7 & 6 \\
\hline Age & Sex + grouped years & 16 & 499.24 & 503.78 & 507.17 & 505.65 & 508.26 & 8 & 8 & 6 & 8 & 8 \\
\hline Grouped ages & Sex + grouped years & 7 & 501.81 & 503.57 & 501.77 & 503.48 & 504.92 & 4 & 5 & 4 & 4 & 4 \\
\hline Sex+grouped ages & Sex + grouped years & 8 & 496.95 & 502.59 & 498.21 & 498.30 & 503.01 & 2 & 3 & 3 & 2 & 3 \\
\hline Sex+time & Sex + grouped years & 14 & 501.94 & 508.03 & 501.72 & 504.17 & 505.91 & 6 & 6 & 8 & 5 & 5 \\
\hline
\end{tabular}

were 78 females, 76 males, and 14 unknown-sex individuals.

Ten CJS model structures were initially fitted to 5 sets of capture histories, each with ages and sexes randomly assigned to individuals for which these factors were unknown. There was strong support among all 5 sets of capture histories for sex- and time-varying recapture probabilities $(p)$. Specifically, females had higher $p$ than males, and the years 2006 and 2015 had lower $p$ compared to 2007 to 2014. The best-fitting model for all capture history datasets had sex differences in survival. There was no statistical support for age differences in survival or time variance during the study years (Table 5).

The best-fitting model structure was fitted to 1000 sets of capture histories (with randomly assigned ages and sex as above), and 1000 pairs of survival parameters were obtained from each fitted model. The median of the resulting distribution of estimated age 2 yr and older female survival was 0.97 compared to 0.94 for males (Table 2, Fig. 5). During most years (2007-2014), estimated median (center 95 ${ }^{\text {th }}$ percentile) recapture probabilities were quite high; 0.98 (0.97-0.99) among females and 0.96 (0.93-0.98) among males. Somewhat lower rates 0.91 (0.83-0.95) among females and 0.79 (0.67-0.88) among males were estimated for 2 years: 2006 and 2015 .

Expected survivorship curves calculated using agespecific survival rate estimates (Table 2) illustrate a steep drop during the first year followed by slow attrition with age (Fig. 6). Although the oldest seals in this study were 12 yr old, the survivorship curves were

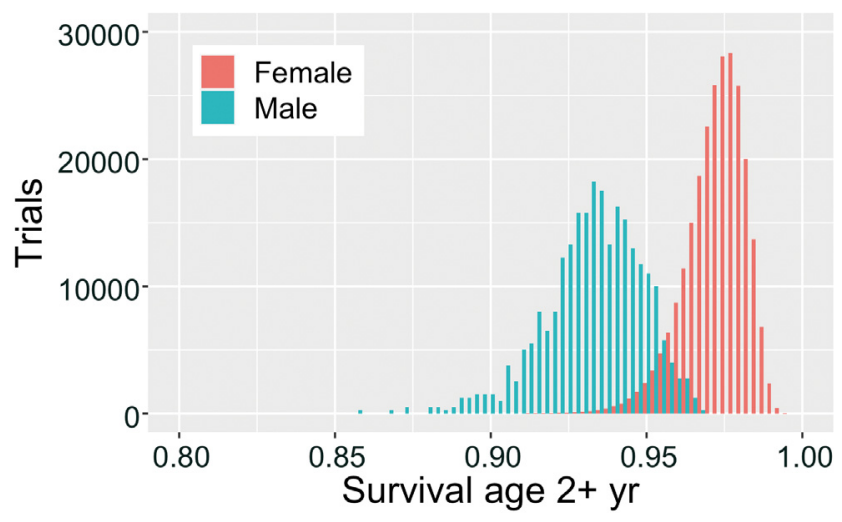

Fig. 5. Distributions of estimated survival rates of female and male Mediterranean monk seals from Cabo Blanco, ages 2 yr and older

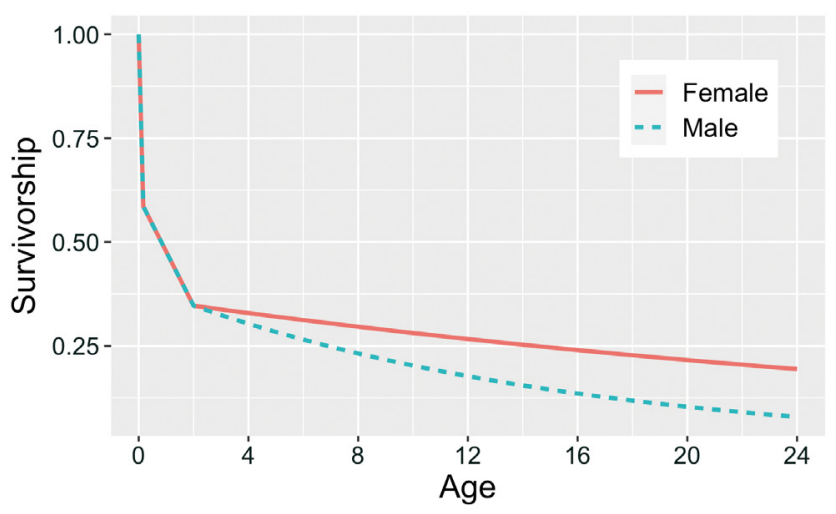

Fig. 6. Survivorship curve for female and male Mediterranean monk seals at Cabo Blanco through age $24 \mathrm{yr}$ 
calculated to age $24 \mathrm{yr}$, assuming a constant survival rate from age $2 \mathrm{yr}$ and older. Should senescence occur, realized lifespans would be shorter than those predicted by assuming constant adult survival.

\subsection{Reproductive rates}

Of the 134 females observed during 2005-2016, 30 were known-age individuals (ranging up to $11 \mathrm{yr}$ old), 83 were first observed as subadults, and 21 were first observed as adults. Random initial ages were assigned to unknown-aged female subadult and adult seals according to the proportions in Table 3. There were 504 known-maternity pups associated with these females, and another 179 pups were of unknown maternity (Table 6).

The fitted reproductive curve, accounting for both uncertainty in female ages as well as uncertainty in the maternity of pups, rose steeply from ages 3-6 yr, reached a broad plateau exceeding 0.80 from ages 7-18 yr, and thereafter declined gradually (Fig. 7). Uncertainty in the birth rate generally increased with age, because there have been few observations of older seals.

The 1000 simulated gross reproductive rate estimates were nearly invariant, ranging only from 0.707 to 0.717 , because the number of pups born during 2005-2016 was constant in each iteration, and the number of reproductive female years only varied from 950 to 969 among all simulations. To better represent uncertainty in the gross reproductive rate, we generated binomial confidence intervals (Wilson

Table 6. Number of Mediterranean monk seal pups born at Cabo Blanco during 2005-2016, according to maternity status. Known and unknown maternity refer to whether pups were associated with an identified mother

\begin{tabular}{|cccc|}
\hline Year & $\begin{array}{c}\text { Known } \\
\text { maternity }\end{array}$ & $\begin{array}{c}\text { Unknown } \\
\text { maternity }\end{array}$ & $\begin{array}{c}\text { Total } \\
\text { born }\end{array}$ \\
\hline 2005 & 14 & 15 & 29 \\
2006 & 30 & 18 & 48 \\
2007 & 41 & 5 & 46 \\
2008 & 38 & 7 & 45 \\
2009 & 47 & 4 & 51 \\
2010 & 44 & 11 & 55 \\
2011 & 49 & 10 & 59 \\
2012 & 49 & 14 & 63 \\
2013 & 47 & 16 & 63 \\
2014 & 51 & 18 & 69 \\
2015 & 49 & 24 & 82 \\
2016 & 45 & 37 & 683 \\
All & 504 & 179 & \\
\hline
\end{tabular}

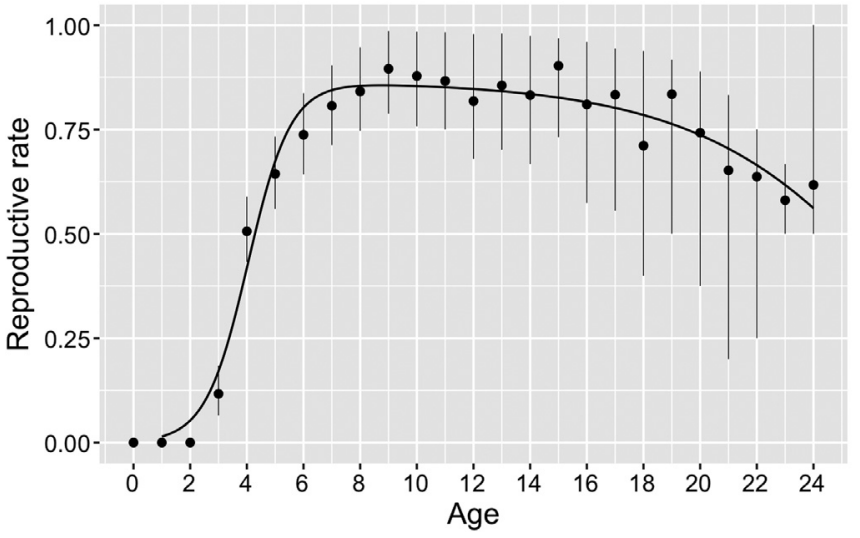

Fig. 7. Estimated age-specific reproductive rates of Mediterranean monk seals at Cabo Blanco, 2005-2016. The solid line represents a 5-parameter reproductive function fitted to distributions at each age. Solid circles are means and bars indicate the associated center $95^{\text {th }}$ percentiles generated by 1000 Monte Carlo simulations

1927, Agresti \& Coull 1998, Harrell 2015). Using 683 pups and the 959 reproductive female years (the median value from the simulations), we estimated a mean gross reproductive rate of $0.71 \quad(95 \% \mathrm{CI}$ : $0.68-0.74)$.

The intrinsic growth rate determined from a Leslie matrix containing point estimates of the vital rates reported above was 1.058 .

\section{DISCUSSION}

\subsection{Survival}

This study provides the first complete set of survival rate estimates for Mediterranean monk seals from birth well into adulthood (age 12 yr). Previously published survival estimates (Table 1) may be compared to those estimated in this study (Table 2). Our estimates for survival from birth to 2 mo of age are somewhat higher than those reported by Gazo et al. (2000) and González et al. (2002), although the confidence intervals from the latter study overlap with ours. Martínez-Jauregui et al. (2012) reported a survival rate for 2.5 to $4 \mathrm{yr}$ old seals that was lower than we estimated for seals older than 2 yr. The same authors also found, as did we, that adult females exhibited higher survival rates than adult males. MartínezJauregui et al. (2012) reported adult female (aged $>4 \mathrm{yr}$ ) rates that were marginally higher than our estimates for females aged $>2 \mathrm{yr}$, perhaps reflecting the different span of ages. Conversely, Martínez-Jauregui et al. (2012) found that adult males had lower survival 
rates than we report here for males older than $2 \mathrm{yr}$, but the authors suggested their adult male survival estimates might have been negatively biased. Notwithstanding the minor discrepancies noted above, the survival estimates from this study (Table 2) are essentially consistent with those previously reported (Table 1) for the same or roughly similar age classes.

Prior to this study, survival from 2 mo to $2 \mathrm{yr}$ of age when most individuals are indistinguishable based upon natural marks, was unknown. We estimated that the proportion of seals that died during this 22 mo period coincidentally matched the proportion surviving just the first 2 mo of life (0.59, Table 2). When annualized, median first-year survival $\left(\phi_{0}\right)$ was 0.46 , and second year survival $\left(\phi_{1}\right)$ was 0.75 . Filling this gap in juvenile survival confirms that the first 2 mo of life are when the highest mortality occurs in this population (Fig. 6).

The survival estimates we report entail some notable strengths as well as caveats. Because no seals migrate out of (nor into) the Cabo Blanco population, our estimates represent actual survival as opposed to the more commonly evaluated apparent survival, in which mortality and emigration are indistinguishable. Further, the survival estimates were based on nearly all individuals in the population at each life stage examined, so that there is virtually no potential for sampling bias. Two sources of negative bias in the estimation of survival from age 2 mo to $2 \mathrm{yr}\left(\phi_{2 \mathrm{mo}-2 \mathrm{yr}}\right)$ were noted in Section 3. A total of 18 seals were first recognized as distinct when they were already adults during 2006-2015 (Table 4). Some of these seals were likely survivors from our study cohorts but were not counted as such because they were not identified as subadults. We can determine an upper bound on the magnitude of bias from this source as follows. Based only on seals appearing in the subadult catalog, we estimated a median $\phi_{2 \mathrm{mo}-2 \mathrm{yr}}$ of 0.59 . Given that value and the fact that 287 pups were known to be alive at age 2 mo during 2003-2012, we expect that 169 of them survived and were identified as subadults. Note that this is slightly lower than the 183 seals that entered the subadult photo-ID catalog during 2005-2015, because randomized age allocation assigned some seals to cohorts before and after 2003-2012. If we liberally assume that all of those 18 seals in Table 4 had been born into the 2003-2012 cohorts, the total survivors to at least age 2 yr would be 187 , and the estimate of $\phi_{2 \mathrm{mo}-2 \mathrm{yr}}$ would rise to 0.65 (187/287) from 0.59 .

A second potential source of negative bias was that some deaths that actually occurred between ages 2 and $3 \mathrm{yr}$ might have been treated as having occurred prior to age 2 yr. This could occur if any 2 yr olds did not yet have sufficient marks to be identifiable and then died before reaching age 3 yr. However, given the high survival (Table 2) of seals over $2 \mathrm{yr}$ of age, this scenario was likely rare.

The annualized survival rates for age 0 and $1 \mathrm{yr}$ assume a constant survival rate during the 22 mo interval from age 2 mo to $2 \mathrm{yr}$. While this assumption may not be correct, any deviation from it would merely reapportion some of the mortality between the first and second year. Any such error would not affect estimated survivorship up to age $2 \mathrm{yr}$.

Age-specific survival rates in pinnipeds often peak at adulthood around age 3-5 yr (Cameron \& Siniff 2004, Baker \& Thompson 2007, Hastings et al. 2012, Condit et al. 2014, Altukhov et al. 2015, DeLong et al. 2017). Here, we found no increase in survival after age 2 yr. It is possible that conditions at Cabo Blanco are sufficiently favorable such that young seals indeed have survival rates as high as adults. Alternatively, uncertainty regarding the ages of most seals, and the randomization process we implemented to reflect that uncertainty, may have blurred any differences between sequential age-specific survival rates so that they were not statistically distinct.

Consistent with Martínez-Jauregui et al. (2012), we found that males older than age $2 \mathrm{yr}$ had somewhat lower survival than females. The difference in survival rate is small (Table 2), and perhaps reflects costs associated with maintaining marine territories and competition for mating opportunities.

\subsection{Reproduction}

Female monk seals at Cabo Blanco began bearing pups as early as age $3 \mathrm{yr}$, and the fitted age-specific reproductive rate curve rose steeply thereafter to more than 0.80 , where it remained until at least the late teens (Fig. 7). This pattern is consistent with other robustly growing phocid seal populations residing in productive environments (Huber et al. 1991, Hammill \& Gosselin 1995). In contrast, the closest relative of the Mediterranean monk seal, the Hawaiian monk seal Monachus schauinslandi, exhibits varying agespecific reproductive patterns among subpopulations, but overall exhibits delayed maturity and lower fecundity (Harting et al. 2007, Robinson et al. 2021). The differences may be related to the species' contrasting foraging seascapes. Cabo Blanco monk seals forage in one of the world's major eastern boundary upwelling ecosystems, the Canary Current system, a very productive region which experiences year- 
round upwelling (Kämpf \& Chapman 2016). In contrast, Hawaiian monk seal foraging habitat is located in relatively oligotrophic subtropical waters (Polovina et al. 2008).

\subsection{Conservation implications}

Survival of monk seal pups during the first 2 mo of life averaged 0.59 at Cabo Blanco. This is unusual among phocids, which typically exhibit considerably higher survival rates prior to weaning (Steiger et al. 1989, Hastings \& Testa 1998, Pomeroy et al. 1999, Auttila et al. 2014). Inter-specific comparisons are somewhat complicated because phocid species wean at different ages, and the published studies measured neonatal survival to different time points. Regardless, it remains clear that Cabo Blanco monk seals consistently exhibit unusually low early survival. Some other species typically enjoy high pup survival, but in special circumstances have comparable or even lower survival than reported at Cabo Blanco. For example, Hawaiian monk seal pups nurse for 5-7 wk, and survival to weaning is typically $\geq 0.90$. However, at one site, predation by Galapagos sharks Carcharhinus galapagensis, heavy surf, and high tides have reduced survival to weaning to as low as 0.57 (Baker et al. 2020). Northern elephant seal Mirounga angustirostris survival to weaning (at about $4 \mathrm{wk}$ of age) is highly variable among colonies and over time (Stewart \& Huber 1993). For example, Stewart \& Yochem (1991) reported that survival to weaning of elephant seals born at San Miguel Island, California (USA), typically exceeded 0.96, whereas Huber et al. (1991) reported a lower rate, averaging 0.72 . During the 1982-1983 El Niño, extremely heavy storm-driven surf washed away hundreds of elephant seal pups at Año Nuevo Island, California, lowering survival to weaning to just 0.30 (Le Boeuf \& Reiter 1991).

In the cases where Hawaiian monk seal and northern elephant seal mortality has been elevated, chronic or episodic factors (high surf or vulnerability to predation) at the nursery grounds were at play. This appears to be the case with Mediterranean monk seals at Cabo Blanco as well, where the caves are directly exposed to inundation. Gazo et al. (2000) reported that pup deaths were significantly associated with high swells, storms, and high tides. It seems likely that Mediterranean monk seals could achieve typically high phocid neonatal survival rates in more hospitable and protected habitat. Prior to human persecution, Mediterranean monk seals gave birth, raised their pups, and rested on open beaches
(Johnson \& Lavigne 1999, González 2015), where neonatal survival rates were probably higher than observed at Cabo Blanco, and perhaps similar to that typical of Hawaiian monk seals and other phocid species. González (2015) suggested that Mediterranean monk seals in the Atlantic are a refugee species relegated to suboptimal and marginal habitat (sea caves) and encouraged the establishment of new populations in the species' former range, preferably on open beaches.

Our study yielded precise vital rate estimates from birth well into adulthood, demonstrating that a conservative hands-off approach to monitoring, based only on observation and avoiding disturbance to animals, need not result in substantially increased bias or uncertainty in the demographic data obtained. Following the neonatal survival bottleneck, Cabo Blanco monk seal survival rates are quite high (Table 2). These findings, coupled with early maturity and high reproductive rates (Fig. 7), evince ample prey resources as well as low levels of non-resource-based threats, such as infectious disease, lethal fishery interactions, or intentional killing, the latter being a primary threat to the species in its eastern Mediterranean range (Karamanlidis et al. 2019). The Cabo Blanco monk seal population rebounded steadily following the 1997 mass mortality event (Martínez-Jauregui et al. 2012). This is evidence that despite low neonatal survival, the aggregate vital rates of the population are favorable for growth. This is further supported by the intrinsic growth rate of 1.058 associated with a Leslie matrix containing the point estimates of survival and fecundity reported herein. The positive trend and favorable vital rates are a testament to the efficacy of the many conservation measures taken under the Action Plan (González et al. 2006).

Despite these positive demographic indicators, the long-term persistence of the monk seal colony at Cabo Blanco remains uncertain. Another mass mortality such as occurred in 1997 (Forcada et al. 1999), or the collapse of one or more of the remaining caves (González et al. 1997), would be catastrophic for this colony. Increasing industrial and artisanal fishing pressure in the waters around Cabo Blanco, episodic illegal fishing intrusions into the no-fishing area adjacent to the colony, and the potential that sea level rise may reduce beach habitat inside the sea caves, all could degrade the favorable vital rates reported here.

The threats outlined above would be difficult, and in some cases probably impossible, to eradicate or even substantially diminish. Whereas approximately half of the global population of Mediterranean monk seals is rather broadly distributed in the eastern 
Mediterranean Sea, nearly all of the other half is highly concentrated in a small area of Cabo Blanco. Consequently, González (2015) and the parties to the Action Plan have recommended experimentation to test the viability of reintroducing monk seals to some portion of their former range, so as to increase total abundance and reduce the risk of extinction in the Atlantic. The ongoing recovery and currently favorable vital rates exhibited by the Cabo Blanco seal population suggest it could well serve as a donor population for a reintroduction effort.

Acknowledgements. We are extremely grateful to the longterm funders of CBD-Habitat's (Conservación de la Biodiversidad y su Hábitat) Monk Seal Conservation Program, including the MAVA Foundation, Ministry for the Ecological Transition and Demographic Challenge of Spain, Fundación Parques Reunidos, Fonds Fiduciaire du Banc d'Arguin et de la Biodiversité Côtière et Marine (BACOMAB), Euronatur and Oceancare, that allowed the continuous, non-invasive monitoring system to remain active and operate for so many years. We are also grateful to Agencia Española de Cooperación Internacional para el Desarrollo (AECID), Save Our Species (SOS/IUCN), United Nations Environmental Program (UNEP), and the United Nations Educational, Scientific and Cultural Organization (UNESCO), which supported various phases of the colony monitoring during the study period. We are also thankful to the authorities of the working group of the Action Plan for the Recovery of Mediterranean Monk Seal in the Eastern Atlantic (Convention on the Conservation of Migratory Species of Wild Animals). We appreciate the support and collaboration of Charles Littnan, Michelle Barbieri, and other members of the United States National Oceanographic and Atmospheric Administration's Hawaiian Monk Seal Research Program.

\section{LITERATURE CITED}

Agresti A, Coull BA (1998) Approximate is better than 'exact' for interval estimation of binomial proportions. Am Stat 52:119-126

Altukhov AV, Andrews RD, Calkins DG, Gelatt TS and others (2015) Age specific survival rates of Steller sea lions at rookeries with divergent population trends in the Russian Far East. PLOS ONE 10:e0127292

Auttila M, Niemi M, Skrzypczak T, Viljanen M, Kunnasranta $M(2014)$ Estimating and mitigating perinatal mortality in the endangered Saimaa ringed seal (Phoca hispida saimensis) in a changing climate. Ann Zool Fenn 51: 526-534

* Badosa E, Grau E, Aparicio F, Layna JF, Cedenilla MA (1998) Individual variation and sexual dimorphism of coloration in Mediterranean monk seal pups (Monachus monachus). Mar Mamm Sci 14:390-393

Badosa E, Pastor T, Gazo M, Aguilar A (2006) Moult in the Mediterranean monk seal from Cap Blanc, western Sahara. Afr Zool 41:183-192

Baker JD, Thompson PM (2007) Temporal and spatial variation in age-specific survival rates of a long-lived mam- mal, the Hawaiian monk seal. Proc R Soc B 274:407-415 Baker JD, Harting AL, Johanos TC, London JM, Barbieri MM, Littnan CL (2020) Terrestrial habitat loss and the long-term viability of the French Frigate Shoals Hawaiian monk seal subpopulation. US Dept. of Commerce. NOAA Tech Memo NOAA-TM-NMFS-PIFSC-107

Belhabib D, Gascuel D, Kane EA, Harper S, Zeller D, Pauly D (2012) Preliminary estimation of realistic fisheries removals from Mauritania, 1950-2010. In: Belhabib D, Zeller D, Harper S, Pauly D (eds) Marine fisheries catches in West Africa, 1950-2010, Part I. Fisheries Centre Research Reports Vol 20, No. 3. University of British Columbia, Vancouver, p 61-75

* Beton D, Broderick AC, Godley BJ, Kolaç E, Ok M, Snape RTE (2021) New monitoring confirms regular breeding of the Mediterranean monk seal in northern Cyprus. Oryx 55:522-525

Cameron MF, Siniff DB (2004) Age-specific survival, abundance, and immigration rates of a Weddell seal (Leptonychotes weddellii) population in McMurdo Sound, Antarctica. Can J Zool 82:601-615

Caughley G, Gunn A (1996) Conservation biology in theory and practice. Blackwell Science, Oxford

Cedenilla MA, M'Bareck H, Haya M, M'Bareck A and others (2017) The ventral patch on the Mediterranean monk seal (Monachus monachus). A tool for life monitoring of males. 31st Conference of the European Cetacean Society, Middelfart. 1-3 May 2017. Abstract only, p 289

* Condit R, Reiter J, Morris PA, Berger R, Allen SG, Le Boeuf BJ (2014) Lifetime survival rates and senescence in northern elephant seals. Mar Mamm Sci 30:122-138

* Dahlgren DK, Guttery MR, Messmer TA, Caudill D, Elmore RD, Chi R, Koons DN (2016) Evaluating vital rate contributions to greater sage-grouse population dynamics to inform conservation. Ecosphere 7:e01249

* DeLong RL, Melin SR, Laake JL, Morris P, Orr AJ, Harris JD (2017) Age-and sex-specific survival of California sea lions (Zalophus californianus) at San Miguel Island, California. Mar Mamm Sci 33:1097-1125

Fioravanti T, Splendiani A, Righi T, Maio N, Lo Brutto S, Petrella A, Caputo Barucchi V (2020) A Mediterranean monk seal pup on the Apulian Coast (southern Italy): sign of an ongoing recolonisation? Diversity 12:258

Forcada J, Aguilar A (2000) Use of photographic identification in capture-recapture studies of Mediterranean monk seals. Mar Mamm Sci 16:767-793

Forcada J, Hammond PS, Aguilar A (1999) Status of the Mediterranean monk seal Monachus monachus in the western Sahara and the implications of a mass mortality event. Mar Ecol Prog Ser 188:249-261

Frederiksen M, Lebreton JD, Pradel R, Choquet R, Gimenez $\mathrm{O}$ (2014) Identifying links between vital rates and environment: a toolbox for the applied ecologist. J Appl Ecol 51:71-81

* Gazo M, Layna JF, Aparicio F, Cedenilla MA, González LM, Aguilar A (1999) Pupping season, perinatal sex ratio and natality rates of the Mediterranean monk seal (Monachus monachus) from the Cabo Blanco colony. J Zool (Lond) 249:393-401

*Gazo M, Aparicio F, Cedenilla MA, Layna JF, González LM (2000) Pup survival in the Mediterranean monk seal (Monachus monachus) colony at Cabo Blanco Peninsula (Western Sahara-Mauritania). Mar Mamm Sci 16: 158-168 
González LM (2015) Prehistoric and historic distributions of the critically endangered Mediterranean monk seal (Monachus monachus) in the eastern Atlantic. Mar Mamm Sci 31:1168-1192

González LM, Aguilar A, López-Jurado LF, Grau E (1997) Status and distribution of the Mediterranean monk seal Monachus monachus on the Cabo Blanco peninsula (Western Sahara-Mauritania) in 1993-1994. Biol Conserv 80:225-233

González LM, Cedenilla MA, de Larrinoa PF, Layna JF, Aparicio F (2002) Changes in the breeding variables of the Mediterranean monk seal (Monachus monachus) colony of Cabo Blanco Peninsula after a mass mortality episode. Mammalia 66:173-182

González LM, Fernández de Larrinoa P, Mas J, M'Barek H and others (2006) The action plan for the recovery of the Mediterranean monk seal in the Eastern Atlantic. OA Parques Nacionales, Ministerio de Medio Ambiente, Madrid

Gucu A, Ok M, Sakinan S (2009) A survey of the critically endangered Mediterranean monk seal, Monachus monachus (Hermann, 1779) along the coast of Northern Cyprus. Isr J Ecol Evol 55:77-82

Hammill MO, Gosselin JF (1995) Grey seal (Halichoerus grypus) from the Northwest Atlantic: female reproductive rates, age at first birth, and age of maturity in males. Can J Fish Aquat Sci 52:2757-2761

Harrell FE Jr (2015) Hmisc: Harrell miscellaneous. R package version 3.17-1. https://CRAN.R-project.org/package $=$ Hmisc

Harting AL (2002) Stochastic simulation model for the Hawaiian monk seal. PhD thesis, Montana State University, Bozeman, MT

Harting AL, Baker JD, Johanos TC (2007) Reproductive patterns of the Hawaiian monk seal. Mar Mamm Sci 23: $553-573$

* Hastings KK, Testa JW (1998) Maternal and birth colony effects on survival of Weddell seal offspring from McMurdo Sound, Antarctica. J Anim Ecol 67:722-740

*Hastings KK, Small RJ, Pendleton GW (2012) Sex-and agespecific survival of harbor seals (Phoca vitulina) from Tugidak Island, Alaska. J Mammal 93:1368-1379

Hernández M, Robinson I, Aguilar A, González LM and others (1998) Did algal toxins cause monk seal mortality? Nature 393:28-29

Huber HR, Beckham C, Nisbet J (1991) Effects of the 1982-83 El Niño on northern elephant seals on the South Farallon Islands, California. In: Trillmich F, Ono KA (eds) Pinnipeds and El Niño. Ecological Studies (Analysis and Synthesis), Vol 88. Springer, Berlin, p 219-233

Johnson WM, Lavigne DM (1999) Monk seals in antiquity. The Mediterranean monk seal (Monachus monachus) in ancient history and literature. Mededelingen 35. Netherlands Commission for International Nature Protection, Leiden

Jones JH (2007) demogR: A package for the construction and analysis of age-structured demographic models in R. J Stat Softw 22:1-28

Kämpf J, Chapman P (2016) Upwelling systems of the world. Springer International Publishing, Switzerland

Karamanlidis A, Dendrinos P (2015) Mediterranean monk seal. Monachus monachus (errata version published in 2017). The IUCN Red List of Threatened Species 2015: e. T13653A117647375
Karamanlidis AA, Dendrinos $\mathrm{P}$, de Larrinoa PF, Gücü AC, Johnson WM, Kiraç CO, Pires R (2016) The Mediterranean monk seal Monachus monachus: status, biology, threats, and conservation priorities. Mammal Rev 46: 92-105

Karamanlidis AA, Adamantopoulou S, Tounta E, Dendrinos P (2019) Mediterranean monk seal. Monachus monachus (Eastern Mediterranean subpopulation). The IUCN Red List of Threatened Species 2019: e.T120868935A1208 69697

Koivuniemi M, Kurkilahti M, Niemi M, Auttila M, Kunnasranta $M$ (2019) A mark-recapture approach for estimating population size of the endangered ringed seal (Phoca hispida saimensis). PLOS ONE 14:e0214269

* Laake JL, Johnson DS, Conn PB (2013) Marked: an R package for maximum-likelihood and MCMC analysis of capture-recapture data. Methods Ecol Evol 4: 885-890

Le Boeuf BJ, Reiter J (1991) Biological effects associated with El Niño Southern Oscillation, 1982-83, on northern elephant seals breeding at Año Nuevo, California. In: Trillmich F, Ono KA (eds) Pinnipeds and El Niño. Ecological Studies (Analysis and Synthesis), Vol 88. Springer, Berlin, p 206-218

Loughlin T, Cunningham L, Gales NJ, Well R, Boyd IL (2010) Marking and capturing. In: Boyd IL, Bowen WD, Iverson SJ (eds) Marine mammal ecology and conservation: a handbook of techniques. Oxford University Press, Oxford and New York, p 16-41

Mackey BL, Durban JW, Middlemas SJ, Thompson PM (2008) A Bayesian estimate of harbour seal survival using sparse photo-identification data. J Zool (Lond) 274:18-27

Martínez-Jauregui M, Tavecchia G, Cedenilla MA, Coulson T, Fernández de Larrinoa P, Muñoz M, González LM (2012) Population resilience of the Mediterranean monk seal Monachus monachus at Cabo Blanco peninsula. Mar Ecol Prog Ser 461:273-281

Nicolaou H, Dendrinos P, Marcou M, Michaelides S, Karamanlidis AA (2019) Re-establishment of the Mediterranean monk seal Monachus monachus in Cyprus: priorities for conservation. Oryx 55(4):526-528

* Osterhaus A, Groen J, Niesters H, van de Bildt M and others (1997) Morbillivirus in monk seal mass mortality. Nature 388:838-839

*Polovina JJ, Chai F, Howell EA, Kobayashi DR, Shi L, Chao Y (2008) Ecosystem dynamics at a productivity gradient: a study of the lower trophic dynamics around the northern atolls in the Hawaiian Archipelago. Prog Oceanogr 77:217-224

* Pomeroy PP, Fedak MA, Rothery P, Anderson S (1999) Consequences of maternal size for reproductive expenditure and pupping success of grey seals at North Rona, Scotland. J Anim Ecol 68:235-253

* Reyero M, Cacho E, Martínez A, Vázquez J, Marina A, Fraga S, Franco JM (1999) Evidence of saxitoxin derivatives as causative agents in the 1997 mass mortality of monk seals in the Cape Blanc peninsula. Nat Toxins 7:311-315

* Robinson SJ, Harting AL, Mercer T, Johanos TC, Baker JD, Littnan CL (2021) Sighting patterns reveal unobserved pupping events to revise reproductive rate estimates for Hawaiian monk seals in the main Hawaiian Islands. Mar Mamm Sci 37:420-432

Samaranch R, González LM (2000) Changes in morphology 
with age in Mediterranean monk seals (Monachus monachus). Mar Mamm Sci 16:141-157

Sandercock BK (2006) Estimation of demographic parameters from live-encounter data: a summary review. J Wildl Manag 70:1504-1520

Steiger GH, Calambokidis J, Cubbage JC, Skilling DE, Smith AW, Gribble DH (1989) Mortality of harbor seal pups at different sites in the inland waters of Washington. J Wildl Dis 25:319-328

Editorial responsibility: Clive McMahon,

Hobart, Tasmania, Australia

Reviewed by: E. Danyer, T. Norris, C. Oosthuizen
Stewart BS, Huber HR (1993) Mirounga angustirostris. Mamm Species 449:1-10

Stewart BS, Yochem PK (1991) Northern elephant seals on the southern California Channel Islands and El Niño. In: Trillmich F, Ono KA (eds) Pinnipeds and El Niño. Ecological Studies (Analysis and Synthesis), Vol 88. Springer, Berlin, p 234-243

Wilson EB (1927) Probable inference, the law of succession, and statistical inference. J Am Stat Assoc 22:209-212

Submitted: February 4, 2021

Accepted: May 19, 2021

Proofs received from author(s): August 10, 2021 